\title{
ŁÓDŹ REGION AND ITS NORTHERN VICINITY UNDER VISTULIAN GLACIATION CONDITIONS
}

\author{
MaŁgorzata Roman, Danuta Dzieduszyńska, Joanna Petera-Zganiacz \\ Department of Geomorphology and Palaeogeography, University of Łódź, Poland \\ Manuscript received: May 30, 2014 \\ Revised version: July 28, 2014
}

\begin{abstract}
Roman M., Dzieduszyńska D., Petera-Zganiacz J., 2014. Łódź region and its northern vicinity under Vistulian Glaciation conditions. Quaestiones Geographicae 33(3), Bogucki Wydawnictwo Naukowe, Poznań, pp. 155-163, 4 figs. DOI 10.2478/quageo-2014-0038, ISSN 0137-477X.

AвSTRACT: An overview of palaeogeographical findings of the last glacial period (MIS 5d-MIS 2) has been given for the Łódź region. Processes which influenced the area outside of ice-sheet margin are presented with respect to space and time, as predominantly driven by different types of periglacial environment. Attention was paid to leading accumulative and erosional processes and resulting landforms, still well-pronounced in the landscape. Recently, the picture of the area discussed, during the Vistulian was completed and identified was the mechanism of the LGM ice-sheet advance onto the Płock lobe. Borderline location of the Eódź region offers comprehensive research on the time and processes and determines its significance on the geomorphological map of Poland.
\end{abstract}

KEY WORDS: periglacial zone, glaciated area, morphogenesis, Vistulian (Weichselian), Płock lobe, Łódź region

Address of the corresponding author: Matgorzata Roman, Department of Geomorphology and Palaeogeography, University of Łódź, Narutowicza 88, 91-139 Łódź, Poland; e-mail: mroman@geo.uni.lodz.pl

\section{Introduction}

Łódź region is understood as the area limited by maximum extents of the late Warta (Saalian) Stadial of the Odranian Glaciation to the south and the Vistulian (Weichselian) Glaciation icesheet to the north, while from the west and east is bounded by river valleys, respectively the Warta and Pilica with Rawka (Fig. 1). Also the area situated within the Płock ice-lobe, the characteristic element of the last Scandinavian ice-sheet margin contour, is taken into account.

Regional Vistulian palaeogeography has been well recognized in various environments: glacial, fluvial, slope and aeolian. The most valuable archive of extraglacial area is provided from organ- ic series filling post-Eemian closed depressions whereas of glaciated area and also periglacial zone is derived from geological and geomorphological evidence. Moreover, interaction between different environments in cool though changing climatic conditions of the Vistulian are well documented.

The article presents a short review of the subject and significance of the Vistulian studies for better understanding of local events and environmental global changes. In the text the authors use the traditional stratigraphic division of the Vistulian (Weichselian) based on palynological premises in the Netherlands as well as the stratigraphy established for the records in the glaciated area (see Fig. 2 column I, IV). 


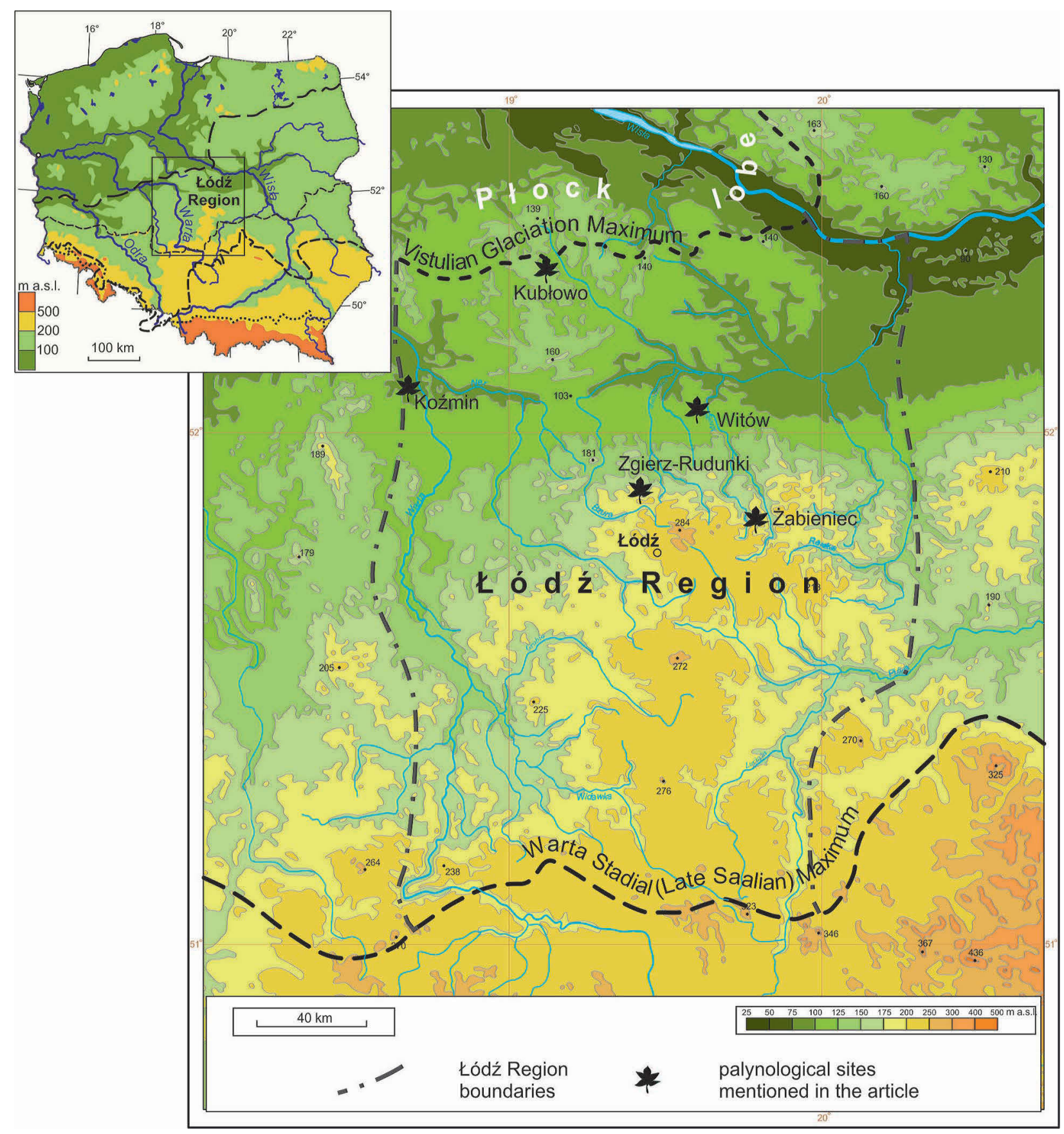

Fig. 1. Location map of the Łódź region

Area outside the last Scandinavian icesheet

At the beginning of the Vistulian, when climate continuously became colder, the best visible changes in environment of the Łódź region were connected with changes in vegetation cover. In the Early Vistulian (MIS 5d - a) (Fig. 2), the deciduous trees gave way to coniferous trees and then vegetation cover attained a shrub tundra nature. Information about these changes is provided from organic infillings of some palaeolakes formed at the decline of the Warta stage, in which accumulation continued through the Eemian Interglacial and embraced Early Vistulian. In pollen diagrams are very clear pronounced interstadials of Amersfoort and Brörup (separately or together) and Odderade (Jastrzębska-Mamełka 1985, Klatkowa 1997, Balwierz, Roman 2002, Roman, Balwierz 2010, Kołaczek et al. 2012). A par- 


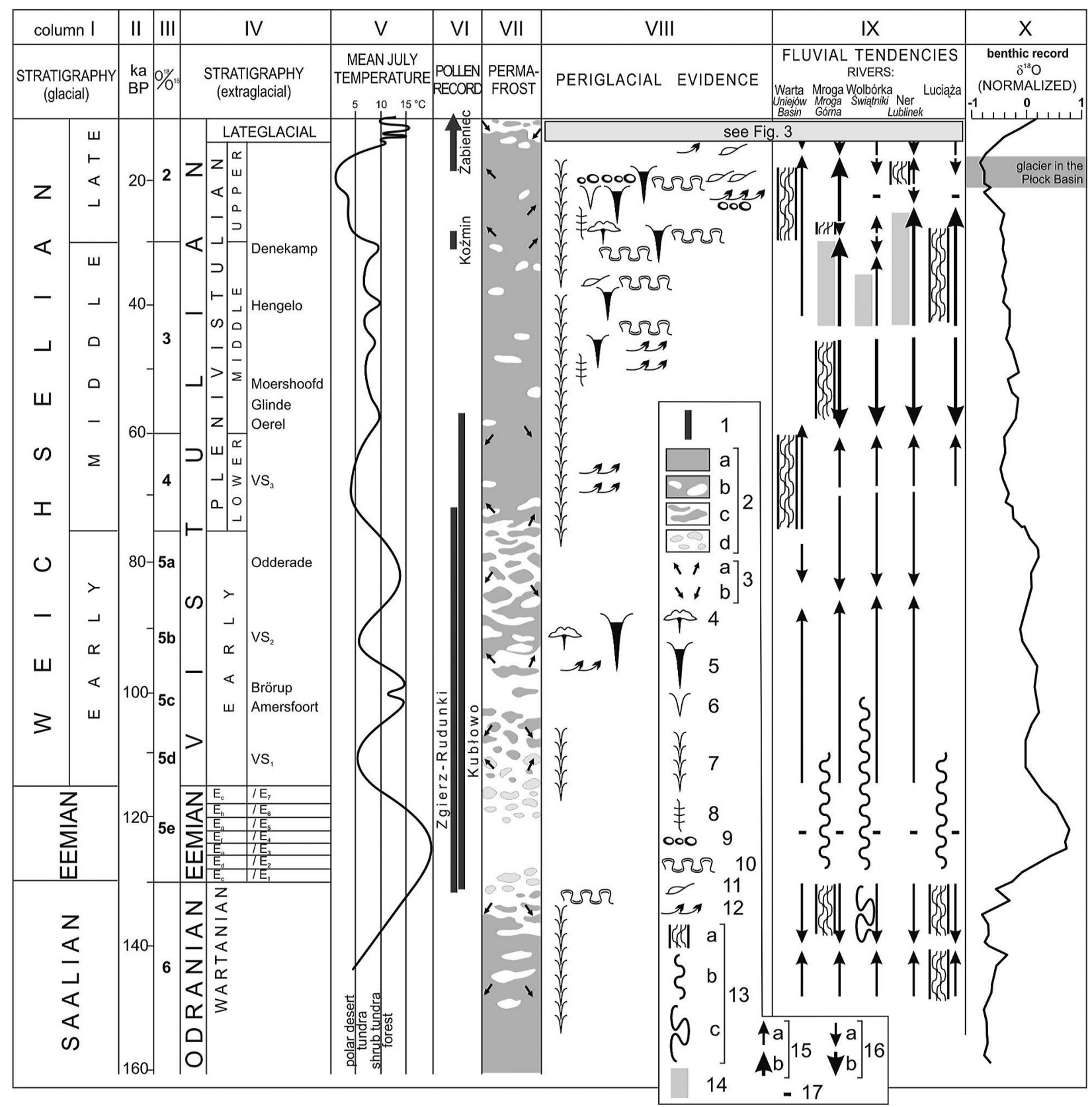

Fig. 2. Features of natural environment in Central Poland during the Warta Stadial - Eemian Interglacial - Vistulian cycle (after Jastrzębska-Mamełka 1985, Martinson et al. 1987, Turkowska 1988, 2006, Klatkowa 1996, Petera 2002, WacheckaKotkowska 2004, Forysiak 2005, Balwierz 2010, Roman, Balwierz 2010)

1 - extent of pollen diagrams; 2 - permafrost: a - continuous, $\mathrm{b}$ - discontinuous, $\mathrm{c}$ - sporadic, $\mathrm{d}$ - seasonal; 3 - tendencies to: a - aggradation,

b - degradation; 4 - hydrolaccolith; 5 - epigenetic ice-wedge pseudomorphs; 6 - sand wedges; 7 - syngenetic ice-wedge pseudomorphs;

8 - frost fissures; 9 - gravelly-stony pavements; 10 - involutions; 11 - solifluction structures; 12 - intense aeolian activity; 13 - river pattern: $\mathrm{a}$ - braided, $\mathrm{b}$ - small meanders, c - large meanders; 14 - backwaters; 15 - tendency to aggradation: $\mathrm{a}$ - medium, $\mathrm{b}$ - intensive; 16 - tendency to erosion: a - medium, $\mathrm{b}$ - intensive; 17 - dynamic balance

ticularly long record of changes in environmental conditions is provided from the Zgierz-Rudunki site (Jastrzębska-Mamełka 1985) and, mostly, the Kubłowo (Roman, Balwierz 2010) (Figs 1, 2 column VI).

In the abiotic environment, influence of the climate cooling in the Early Vistulian was ex- pressed subtly. Intensification of slope processes recorded for the stadials was not sufficiently enough to interrupt the biogenic sedimentation in closed depressions (Wieczorkowska 1975, Klatkowa 1997). In river valleys weak tendencies to aggradation occurred (Turkowska 1988, Petera 2002, Forysiak 2005) and first symptoms of insu- 
lar or discontinuous permafrost appeared (Klatkowa 1996) (Fig. 2 column VII).

Significant cooling of the Lower Plenivistulian (older part of the Middle Weichselian; MIS 4) is correlated with the Świecie hypothetical ice-sheet advance (Lindner 1992, Mojski 2005). Its geological evidence are extraglacial lacustrine deposits reported from the northern part of the region (Roman 2003) and from the Kubłowo pollen profile (Roman, Balwierz 2010). Continuous permafrost with a trend to aggrade occurred (Klatkowa 1996), which is supported by the presence of ice wedge casts (Klatkowa 1996, Petera 2002) (Fig. 2 column VIII). During the Lower Plenivistulian the first phase of intense erosion took place in river valleys (Turkowska 1988, 2006), although in the Warta valley some aggradational stretches existed (Krzemiński 1965), while within the Uniejów Basin depositional environment is interpreted as a sand-bed braided river (Petera 2002) (Fig. 2 column IX).

In evolution of the Łódź region relief, especially in the edge zone of the Łódź Plateau, formation of dry valleys due to concentrated slopewash over frozen ground played an important role. The process was initiated at the turn of the Lower and Middle Plenivistulian (Klatkowa 1997).

The Middle Plenivistulian (younger part of the Middle Weichselian; MIS 3) was a period in which intensive morphogenetic processes occurred. Slope processes influenced other sedimentary environments (Dylik 1972, Wieczorkowska 1975). The river valleys experienced strong aggradation. The delivery of the material was due to not only longitudinal transport, but also from the valley slopes and the effect of these processes was the rhythmically bedded silt and sand (e.g. Klatkowa 1965, Turkowska 1975, 1988) (Fig. 2 column IX). In the bottoms of some valleys there were shallow extensive pools (Turkowska 1988), in other cases, such as in some parts of the Warta valley bottom peatbogs were formed, after which the horizons of organic deposits remained (Forysiak et al. 1999, Petera 2002, Forysiak 2005).

The geological record in many localities of the Łódź region contains evidence for the formation of ice wedges, indicative of permafrost conditions (Fig. 2 column VIII). The apogee of the development of such structures is associated with the period of the Upper Plenivistulian (part of Late Weichselian; part of MIS 2), when sand wedges also developed (e.g. Dylik 1963, Goździk 1973, Klatkowa 1996, Petera-Zganiacz 2011, 2013). Very cold conditions of an arctic desert promoted aeolian processes, reflected, among others, in an increased amount of wind-abraded grains in alluvia (Goździk 2007, Manikowska 1995, Petera 2002, Wachecka-Kotkowska 2004, Forysiak 2005) or the formation of the autochtonic stone pavement with ventifacts on the plains (e.g. Klatkowa 1965, Dylik 1967, Goździk 1973). Intensive slope processes contributed to the development of the allochtonic stone pavement on the slopes and in the dry valleys (Klatkowa 1965, Dylik 1967, Wieczorkowska 1975).

Despite very severe climatic conditions, vegetation cover could have been present under favourable circumstances, as evidenced by the organic inserts within Upper Plenivistulian depositional series (e.g. Turkowska 1988, Petera, Forysiak 2003) (Fig. 2 column IX). Strong aggradation in the river valleys evolution predominate. Braided pattern was common in river systems (e.g. Turkowska 1988, Petera 2002, Wachecka-Kotkowska 2004, Forysiak 2005). In numerous valleys of the region, the Plenivistulian terrace is the best pronounced element, as a rule formed of sandy-silty series covered by sandy or sandy-gravelly deposits (e.g. Turkowska 1988).

Transformation of the environment in the close of the last glacial cycle (Weichselian Lateglacial, termination of MIS 2) took place under conditions of a general progressive warming. In the stratigraphical division based on a terrestrial record from the Łódź region (Fig. 3), the end of the Late Vistulian encompasses three warm units (Kamion Phase, Bölling, Alleröd) and three cool units (Oldest Dryas, Older Dryas and the longest and coldest, Younger Dryas).

The most complete pollen profiles covering the Lateglacial are available from the sites Witów (Wasylikowa 1999) and Żabieniec (Balwierz 2010) (Figs 1, 2). The former is a profile of more than a local importance, moreover, it was possible to correlate its Younger Dryas section with record of the Gościąż Lake (Ralska-Jasiewiczowa et al. 1998). Within the last decade, a number of palaeoecological data on the environmental conditions increased. From two sites, Żabieniec and Koźmin 


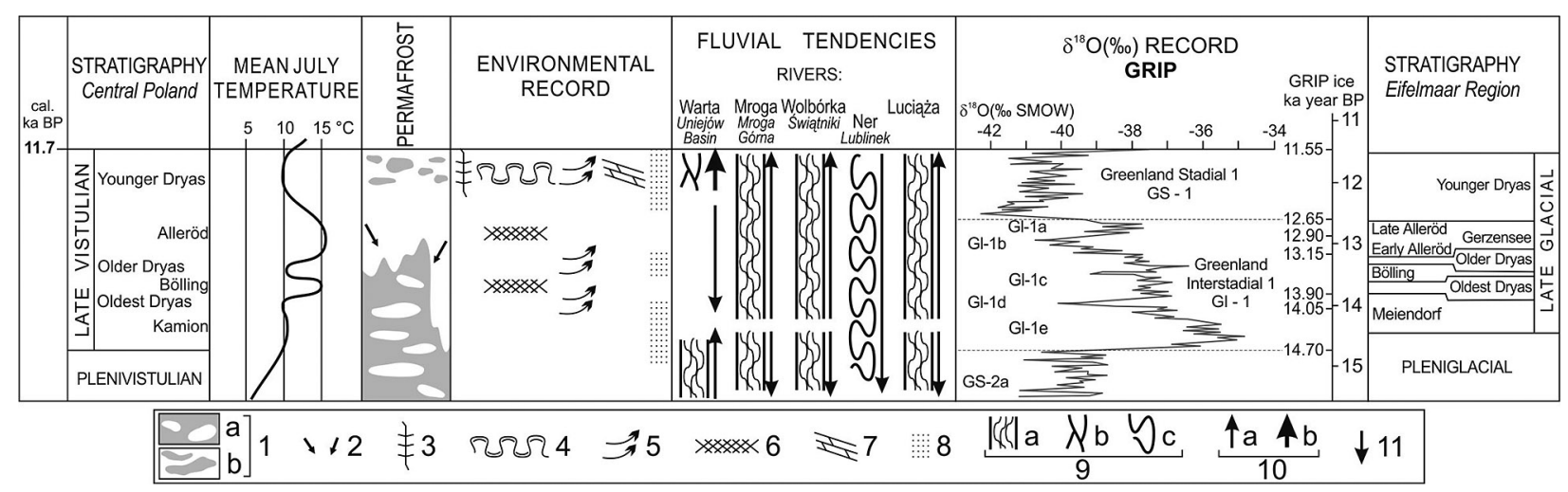

Fig. 3. Features of natural environment in Central Poland during the Late Vistulian (after Dylikowa 1967, Klatkowa 1984, 1996, Turkowska 1988, 2006, Manikowska 1995, Björck et al. 1998, Litt et al. 2001, Petera 2002, Wachecka-Kotkowska 2004, Dzieduszyńska 2011)

1 - permafrost: $\mathrm{a}$ - discontinuous, $\mathrm{b}$ - sporadic; 2 - tendencies to degradation; 3 - frost fissures; 4 - involutions; 5 - intense aeolian activity; 6 - soil horizons; 7 - over-snow deposits; 8 - thinly laminated sands; 9 - river pattern: $\mathrm{a}$ - braided, $\mathrm{b}$ - anabranching, $\mathrm{c}$ - large meanders; 10 tendency to aggradation: $\mathrm{a}$ - medium, $\mathrm{b}$ - intensive; 11 - tendency to medium erosion

Las, chironomid-based quantitative inferences of mean summer temperatures are provided (Płóciennik et al. 2011, Dzieduszyńska et al. 2014).

In the mentioned site Koźmin Las, located in the Warta valley, a multidyscyplinary study provided a high resolution record of the variability of environment for the time frame Alleröd/Younger Dryas turn - Younger Dryas. In situ tree trunks rooted in the organic-rich sediment sequence allowed to reconstruct a series of short local events interrupted by flood episodes in response to the Younger Dryas cooling (Dzieduszyńska et al. 2014).

The Lateglacial morphogenetic processes took place under conditions of permafrost disappearance (Fig. 3). In Central Poland, similar to the north-western European territory, final permafrost retreat occurred in the Alleröd. Studies from the Łódź region provide some basis of its reactivation in the Younger Dryas, such as possible presence of ice wedges (Manikowska 1995, Goździk 1996) or indirect indicators including flat-bottomed involutions (Petera 2002). Positive erosional balance in the river valleys during the Lateglacial led to their deep incision, which resulted in the morphological emergence of the Plenivistulian terrace in the region (e.g. Turkowska 1988, Wachecka-Kotkowska 2004, Forysiak 2005). The channel pattern and tendency to erosion or aggradation, depended on local conditions (cf. Turkowska, Dzieduszyńska 2011). The reversal of this trend in the Younger Dryas caused a tendency to intensified braiding or multichanneling, or meandering persisted
(Turkowska 1995, Turkowska et al. 2004) (Fig. $3)$. The leading hillslope process was wash. The sedimentary archives point to the formation of the series of thinly laminated deposits, in the Younger Dryas accumulated on the snow and fashioned as so-called over-snow deposits - Fig. 3 (Klatkowa 1965, 1984, Dzieduszyńska 2011), developing mostly on east- and north-facing slopes (Turkowska 2006). The Lateglacial evolution of aeolian sedimentary system is pronounced in the common dune formation interrupted with development of well-preserved fossil soils (e.g. Dylikowa 1967, Krajewski 1977, Manikowska 1995, Goździk 2007). Sands were derived from broad Plenivistulian terraces, gradually drained as a result of a positive balance of erosion.

\section{Area within the last Scandinavian ice- sheet extent}

The northern part of the region has been embraced by the Płock lobe (Fig. 1) which is being referred to the glacier that invaded the territory of Poland flowing southward along the Vistula palaeovalley, reached the Płock Basin and the surrounding morainic plateaux, and, finally delineated maximum extent of the ice sheet during the Last Glacial Maximum (LGM) in Central Poland. The number, extent and age of glacial events in the Płock lobe area during the Vistulian Glaciation have been largely debated (e.g. Skompski 1969, Marks 1988, 2010, Baraniecka 1989, Roman 2003, 2010, Wysota et al. 2009). 


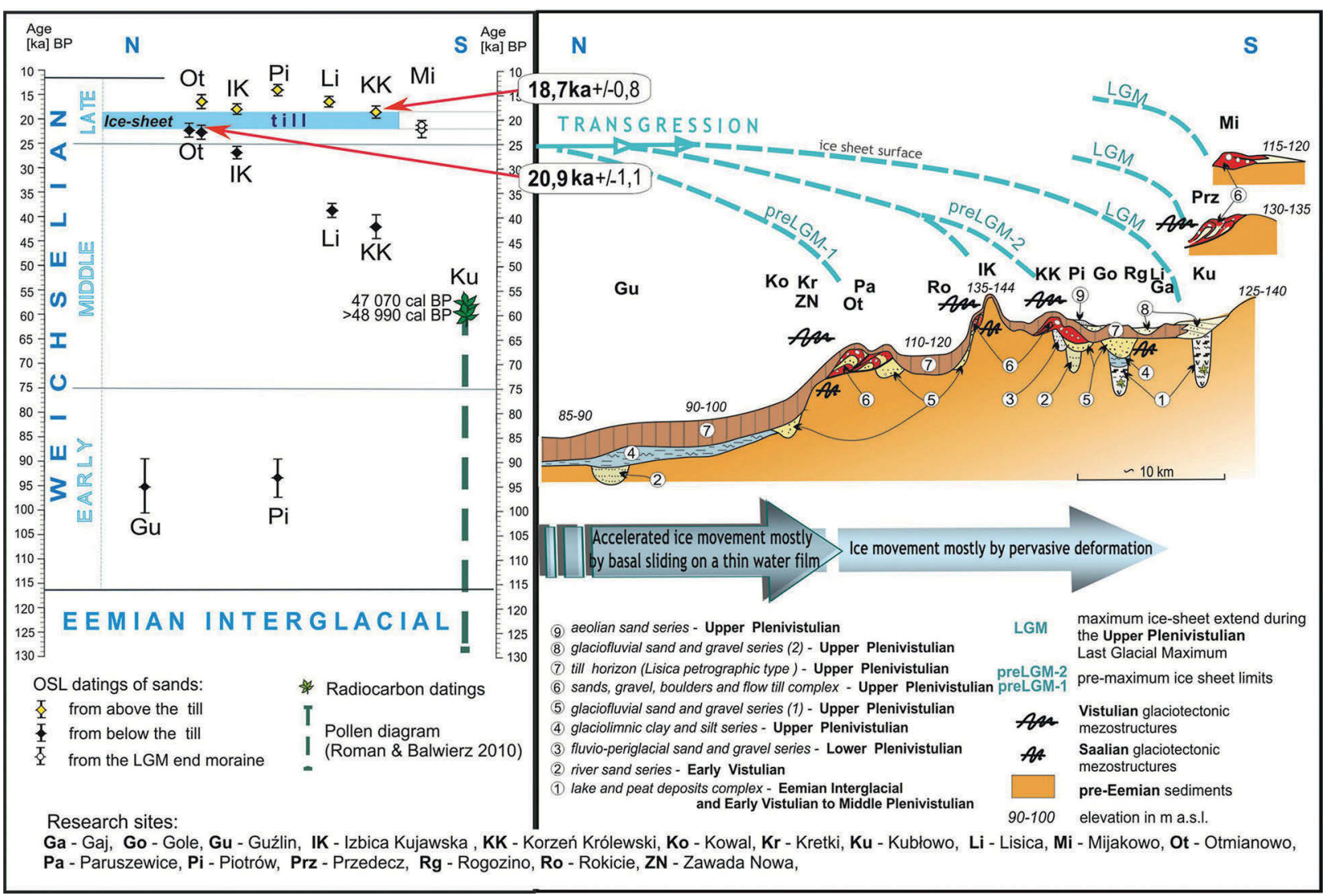

Fig. 4. Lithostratigraphy and time-distance model of the Płock lobe (after Roman 2010, modified)

As shown in recent geological investigations carried out in the Płock lobe area any possible icesheet advance at earlier Vistulian (Weichselian) (Saalian) cold stages (i.e. MIS 5d or MIS 5b; MIS 4 ) has been disclaimed. Prevalent climatic conditions of that time determined as reflected in vegetation development and Cladocera evolution recorded at the Kubłowo profile (Roman, Balwierz 2010, Niska, Roman 2014) (Fig. 2 columns VI, X) also support the opinion. Only a singular glacial event occurred in the Late Vistulian (Late Weichselian, MIS 2). Age of the ice-sheet advance is given by thermoluminescence datings, and is believed to fall between 22.9 and 18.7 OSL ka (Roman 2010) (Fig. 4).

Another argument, supporting one only advance of the last ice-sheet onto the Płock lobe area is litho- and kinetostratigraphy (Roman 2010). Documented in a number of exposures glaciotectonic mezostructures were studied in disturbed sediment sequences. From this, the direction of ice movement which caused the deformations can be deduced and used as a stratigraphic indicator. Two kinetostratigraphic units were distin- guished i.e. the older, the Odranian (Saalian) Glaciation and younger, the Vistulian (Weichselian) manifesting itself by a progressive sequence indicative for a singular deformative transgression cycle. Important for palaeogeography and assessment of the Płock ice lobe dynamics is, that the progressive sequence pertains as well the glaciomarginal zones allocated in the hinterland of the maximum extent of the ice sheet during LGM. Proved was, that the transverse ranges in the LGM hinterland are overridden end moraines. Ranges determined as preLGM- 1 and preLGM-2 were being formed during short standstills of transgression along transverse terrain obstacles (Fig. 4). The results obtained allow to abrogate earlier findings, mainly based on morphostratigraphic criteria, treating of an oscillative-recessive nature of the LGM hinterland zones examined (e.g. Galon, Roszkówna 1967, Niewiarowski 1983, Pasierbski 1984, Mojski 2005).

Maximum limit of the Late Vistulian ice sheet in the Płock area has been reconstructed by means of geomorphological and lithostratigraphical evidence (Skompski 1969, Baraniecka 
1989, Roman 2003) and recently also by sedimentological research and luminescence datings of the glacial sequence in several key exposures (Roman 2010). However, the LGM ice sheet extent has been precisely delineated only in the western part of the area occupied by the Płock ice lobe, but in the central and easternmost part it is still being unrevealed, especially because of an unclear origin and age of landforms within the glaciomarginal zone or because of subsequent river erosion placed in the Płock Basin. Whether the Eemian deposits in sites located in the glaciomarginal zone have been till-covered, provides sufficient reliable evidence to establish the limit of the Last Glacial Maximum ice sheet in Central Poland (Baraniecka 1989, Bruj, Roman 2007, Roman, Balwierz 2010).

Parameters for the dynamics and geometry of the ice-masses inflow were also elaborated and admit to accept as valid that the Płock lobe evolved at the end of the fast moving ice stream and was intensively fed from its hinterland (Roman 2007, 2010, Narloch et al. 2013). That distinctive element of the LGM margin contour has featured the main ice flow artery in the distal part of the Vistula palaeo-ice stream.

\section{Final remarks}

A rich research material gathered through many years of intensive studies over the last cold period in the Łódź region allows for the reconstruction of environmental variability and relief evolution of the area, appropriate to both morphogenetic zones, glacial and periglacial, and determines the region an important place on the geomorphological map of Poland. Geological and geomorphological evidence, well recognized through multidisciplinary studies, including novel geochronological and palaeoecological data, continuously refine knowledge on Vistulian (Weichselian) events and their expression in the stratigraphy (Figs 2, 3, 4). Thus, from a present-day perspective we can say that well-documented findings of the last cold period delivered a quite complete picture of environmental conditions and regional palaeogeography, and also have universal significance for recognising variations of palaeoclimate in higher resolution.

\section{References}

Balwierz Z., 2010. Analiza pyłkowa osadów torfowiska Żabieniec. In: Twardy J., Żurek S., Forysiak J. (eds), Torfowisko Żabieniec: warunki naturalne, rozwój $i$ zapis zmian paleoekologicznych w jego osadach. Bogucki Wydawnictwo Naukowe, Poznań: 179-188.

Balwierz Z., Roman M., 2002. A new Eemian Interglacial to Early Vistulian site at Łanięta, central Poland. Geological Quarterly 26, 2: 207-217.

Baraniecka M.D., 1989. Zasięg lądolodu bałtyckiego w świetle stanowisk eemskich na Kujawach. Studia i Materiaty Oceanologiczne 56, Geologia Morza 4: 131-135.

Björck S., Walker M., Cwynar L., Johnsen S., Knudsen K.-L., Lowe J., Wohlfarth B. and INTIMATE Members, 1998. An event stratigraphy for the last Termination in the North Atlantic region based on the Greenland ice-core record: a proposal by the INTIMATE group. Journal of Quaternary Science 13: 238-292.

Bruj M., Roman M., 2007. Zasięg pojezierza z interglacjału eemskiego w Polsce a pozycja stratygraficzna lądolodów zlodowaceń środkowopolskich (The Eemian Lakeland extent in Poland versus stratigraphical position of the Middle Polish Glaciations). Biuletyn Państwowego Instytutu Geologicznego 425: 27-34.

Dylik J., 1963. Nowe problemy wiecznej zmarzliny plejstoceńskiej (Problèmes nouveaux du pergélisol pléistocène). Acta Geographica Lodziensia 17.

Dylik J., 1967. The main elements of Upper Pleistocene paleogeography in Central Poland. Biuletyn Peryglacjalny 16: 85-115.

Dylik J., 1972. Rôle du ruissllement dans le modélé périglaciaire. Gottinger Geographische Abhandlungen 69: 169-180.

Dylikowa A., 1967. Wydmy śródlądowe i ich znaczenie dla stratygrafii schyłkowego plejstocenu. In: Galon R., Dylik J. (eds), Czwartorzęd Polski. PWN, Warszawa: 353-371.

Dzieduszyńska D., 2011. Ochłodzenie młodszego dryasu i jego efekty morfogenetyczne $\mathrm{w}$ regionie łódzkim (Younger Dryas cooling and its morphogenetic importance in the Łódź Region, Central Poland). Acta Geographica Lodziensia 98.

Dzieduszyńska D.A, Kittel P., Petera-Zganiacz J., Brooks S.J, Korzeń K., Krąpiec M., Pawłowski D., Płaza D.K., Płóciennik M., Stachowicz-Rybka R., Twardy J., 2014. Environmental influence on forest development and decline in the Warta River valley (Central Poland) during the Late Weichselian. Quaternary International 324: 99-14.

Forysiak J., 2005. Rozwój doliny Warty między Burzeninem i Dobrowem po zlodowaceniu warty (The development of the Warta River valley between Burzenin and Dobrów in the Late Quaternary period). Acta Geographica Lodziensia 90.

Forysiak J., Miotk-Szpiganowicz G., Petera J., 1999. Geologic setting and palynologic examination of the Vistulian sediments at Koźmin near Turek, Central Poland. Geological Quarterly 43(1): 85-98.

Galon R., Roszkówna L., 1967. Zasięgi zlodowaceń skandynawskich i ich stadiałów recesyjnych na obszarze Polski. In: Galon R., Dylik J. (eds), Czwartorzęd Polski. PWN, Warszawa: 18-38.

Goździk J.S., 1973. Geneza i pozycja stratygraficzna struktur peryglacjalnych w Środkowej Polsce (Origin and stratigraphical position of periglacial structures in the Middle Poland). Acta Geographica Lodziensia, 31. 
Goździk J.S., 1996. A permafrost evolution and its impact on some depositional conditions between 20 and $10 \mathrm{ka}$ in Poland. Biuletyn Peryglacjalny 34: 53-72.

Goździk J.S., 2007. The Vistulian aeolian succession in central Poland. Sedimentary Geology 193: 211-220.

Jastrzębska-Mamełka M., 1985. Interglacjał eemski i wczesny vistulian w Zgierzu-Rudunkach na Wyżynie Łódzkiej (The Eemian Interglacial and the Early Vistulian at Zgierz-Rudunki in the Łódź Plateau). Acta Geographica Lodziensia 53.

Klatkowa H., 1965. Niecki i doliny denudacyjne w okolicach Łodzi (Vallons en berceau et vallées sèches aux environs de Łódź). Acta Geographica Lodziensia 19.

Klatkowa H., 1984. Osady depozycji naśnieżnej późnego vistulianu (Over-snow deposition of the Late Vistulian sediments). Acta Geographica Lodziensia 50: 51-72.

Klatkowa H., 1996. Symptoms of the permafrost presence in Middle Poland during the last 150000 years. Biuletyn Peryglacjalny 35: 45-86.

Klatkowa H., 1997. Remarks on the palaeogeography of Middle Poland during the Neopleistocene time in the light of investigations of deposits of closed depressions. Quaternary Studies in Poland 14: 41-52.

Kołaczek P., Karpińska-Kołaczek M., Petera-Zganiacz J., 2012. Vegetation patterns under climate changes in the Eemian and Early Weichselian in central Europe inferred from a palynological sequence from Ustków (Central Poland). Quaternary International 268: 9-20.

Krajewski K., 1977. Późnoplejstoceńskie i holoceńskie procesy wydmotwórcze w pradolinie warszawsko-berlińskiej (Late Pleistocene and Holocene dune-forming processes in the Warsaw-Berlin Pradolina). Acta Geographica Lodziensia 39.

Krzemiński T., 1965. Przełom doliny Warty przez Wyżynę Wieluńską (La percée de la vallé de la Warta par le plateau de Wieluń). Acta Geographica Lodziensia 21.

Lindner L., 1992. Stratygrafia (klimatostratygrafia) czwartorzędu. In: L. Lindner (ed.) Czwartorzęd. Osady, metody badań, stratygrafia. Wydawnictwo PAE, Warszawa: 441633.

Litt T., Brauer A., Goslar T., Merkt J., Bałaga K., Müller H., Ralska-Jasiewiczowa M., Stebich M., Negendank J.F.M., 2001. Correlation and synchronisation of Lateglacial continental sequences in northern central Europe based on annually laminated lacustrine sediments. Quaternary Science Reviews 20: 1233-1249.

Manikowska B., 1995. Aeolian differentiation in the area of Poland during the period 20-8 BP. Biuletyn Peryglacjalny 34: 125-164.

Marks L., 1988. Relation of substrate to the quaternary paleorelief and sediments, western Mazury and Warmia (Northern Poland). Zeszyty Naukowe AGH, Geologia 14(1): $1-76$.

Marks L., 2012. Timing of the Late Vistulian (Weichselian) glacial phases in Poland. Quaternary Science Review 44: 81-88.

Martinson D.G., Pisias N.G., Hays J.D., Imbrie J., Moore T.C., Shackleton N.J., 1987. Age dating and the orbital theory of the ice ages: development of a high-resolution 0 to 300 000-year chronostratigraphy. Quaternary Research 27: $1-29$.

Mojski J.E., 2005. Ziemie polskie w czwartorzędzie. Zarys morfogenezy. PIG, Warszawa.

Narloch W., Wysota W., Piotrowski J.A. 2013. Sedimentological record of subglacial conditions and ice sheet dynam- ics of the Vistula Ice Stream (north-central Poland) during the Last Glaciation. Sedimentary Geology 293: 30-44.

Niewiarowski W., 1983. Postglacjalne ruchy skorupy ziemskiej na Pojezierzu Kujawskim w świetle badań geomorfologicznych. Przeglad Geograficzny 55(1): 13-31.

Niska M., Roman M, 2014. Development of the Kubłowo palaeolake, central Poland, during the Eemian Interglacial as against of subfossil Cladocera analysis - preliminary results. Studia Quaternaria 31(1). DOI: 102478/squa-20140003

Pasierbski M., 1984. Struktura moren czotowych jako jeden ze wskaźników sposobu deglacjacji obszaru ostatniego zlodowacenia w Polsce. Rozprawy UMK, Torun.

Petera J., 2002. Vistuliańskie osady dolinne w basenie uniejowskim i ich wymowa paleogeograficzna (Vistulian valley deposits in the Uniejów Basin and their palaeogeographical significance). Acta Geographica Lodziensia 83.

Petera-Zganiacz J., 2011. Changes in the development of frost wedges in the middle Warta valley deposits (Central Poland). Geologija 53,1 (73): 15-20.

Petera-Zganiacz J., 2013. Zapis procesów peryglacjalnych i wiek szczelin kontrakcji termicznej w południowo-zachodniej części poziomu katarzynowskiego (Polska środkowa) (Record of periglacial processes and age of the thermal contraction structures in the southwestern part of the Katarzynów Level (Central Poland). Acta Geographica Lodziensia 101: 101-115.

Petera J., Forysiak J., 2003. The last ice sheet extent in Central Poland. Geological Quarterly 47(4): 574-578.

Płóciennik M., Self A., Birks H.J.B., Brooks S.J., 2011. Chironomidae (Insecta: Diptera) succession in Żabieniec bog and its palaeo-lake (Central Poland) through the Late Weichselian and Holocene. Paleogeography, Palaeoclimatology, Palaeoecology 307: 150-167.

Ralska-Jasiewiczowa M., Goslar T., Madeyska T., Starkel L. (eds), 1998. Lake Gościąż, central Poland. A monographic study. Part 1. W. Szafer Institute of Botany, Polish Academy of Science, Kraków.

Roman M., 2003. Rozwój rzeźby plejstoceńskiej okolic Gostynina (Development of the Pleistocene relief in the vicinity of Gostynin). Acta Geographica Lodziensia 84.

Roman M., 2007. Rekonstrukcja kierunku ruchu lądolodu lobu Wisły na obszarze Pojezierza Kujawskiego i Kotliny Płockiej (Reconstruction of the ice flow directions of the Vistula ice sheet lobe in the Kujawy Lakeland and the Płock Basin). Acta Geographica Lodziensia 93: 67-85.

Roman M., 2010. Rekonstrukcja lobu płockiego w czasie ostatniego zlodowacenia (Reconstruction of the Płock ice lobe during the last glaciations). Acta Geographica Lodziensia 96.

Roman M., Balwierz Z., 2010. Eemian and Vistulian pollen sequence at Kubłowo (Central Poland): implications for the limit of the Last Glacial Maximum. Geological Quarterly 54(1): 55-68.

Skompski S., 1969. Stratygrafia osadów czwartorzędowych wschodniej części Kotliny Płockiej (Stratigraphy of Quaternary deposits of the eastern part of the Płock Depression). Biuletyn Instytutu Geologicznego 220: 175-258.

Turkowska K., 1975. Rzeczne procesy peryglacjalne na tle morfogenezy doliny Mrogi (Processus fluviaux périglaciaires sur le fond de la morphogenèse de la vallée de la Mroga). Acta Geographica Lodziensia 36.

Turkowska K., 1988. Rozwój dolin rzecznych na Wyżynie Łódzkiej w późnym czwartorzędzie (Évolution des 
vallées fluviatiles sur le Plateau de Łódź au cours du Quaternaire tardif). Acta Geographica Lodziensia 57.

Turkowska K., 1995. Recognition of valleys evolution during the Pleistocene-Holocene transition in non-glaciated region of Polish Lowland. Biuletyn Peryglacjalny 34: 209-227.

Turkowska K., 2006. Geomorfologia regionu łódzkiego. Wydawnictwo UŁ, Łódź.

Turkowska K., Dzieduszyńska D., 2011. Local evidence of landform evolution vs. global changes - a case of Younger Dryas study in the upper Ner Valley system, central Poland. Geographia Polonica 84(1): 147-162.

Turkowska K., Forysiak J., Petera J., Miotk-Szpiganowicz G., 2004. A Warta River system during the Younger Dryas in the Koło Basin (Middle Poland). Quaestiones Geographicae 23: 83-107.

Wachecka-Kotkowska L., 2004. Ewolucja doliny Luciąży uwarunkowania klimatyczne a lokalne (Evolution of the
Luciąża River valley - local and climatic conditions). Acta Geographica Lodziensia 86.

Wasylikowa K., 1999. Przemiany roślinności jako odbicie procesów wydmotwórczych i osadniczych w młodszym dryasie i holocenie na stanowisku archeologicznym $\mathrm{w}$ Witowie koło Łęczycy (Younger Dryas and Holocene vegetation changes as the reflection of eolian processes and human activity at the archaeological site Witów near Łęczyca). Prace i Materiały Muzeum Archeologicznego i Etnograficznego w Łodzi 41: 43-79.

Wieczorkowska J., 1975. Rozwój stoków Pagórków Romanowskich na tle paleogeografii obszaru (L'évoluion des versants des Collines de Romanów a la lumière de la paléogéographie). Acta Geographica Lodziensia 35.

Wysota W., Molewski P., Sokołowski R.J., 2009. Record of the Vistula ice lobe advances in the Late Weichselian glacial sequence in north-central Poland. Quaternary International 207(1-2): 26-41. 